\title{
The Roles and Functions of Occupational Health Nurses in Brazil and in the United States
}

\author{
Maria Helena Palucci Marziale ${ }^{1}$ \\ Oi Saeng Hong ${ }^{2}$ \\ Judy A. Morris ${ }^{3}$ \\ Fernanda Ludmilla Rossi Rocha ${ }^{4}$
}

Cross-sectional exploratory research developed to outline the roles and functions of occupational health nurses (OHNs) in Brazil and compare them with those in the United States. The sample consisted of 154 Brazilian occupational health nurses. First, the instrument Job Analysis Survey of Occupational Health Nursing Practice was translated into Portuguese, followed by data collection and data analysis, comparing the results of the proposed study in Brazil with the findings of a job delineation study conducted in the United States. It was found that most were women, white, between 41 and 50 years of age and working primarily at hospitals or medical centers as clinicians and managers/administrators. Besides, it was found that most Brazilian OHNs spend more time in managerial roles, followed by consultant and educator responsibilities while, in the United States, OHNs spend significantly more time in education/advisory roles.

Descriptors: Nursing; Occupational Health; Occupational Health Nursing; Professional Practice.

\footnotetext{
${ }^{1}$ RN, PhD, Full Professor, Escola de Enfermagem de Ribeirão Preto, Universidade de São Paulo, WHO Collaborating Centre for Nursing Research Development, SP, Brazil. E-mail: marziale@eerp.usp.br.

${ }^{2}$ RN, PhD, Associate Professor, School of Nursing of University of California, USA. E-mail: OiSaeng.Hong@nursing.ucsf.edu.

${ }^{3}$ RN, MS, COHN-S/CM, FAAOHN, Morning Star Health Inc., Grand Rapids, Michigan, USA. E-mail: judyamorris@comcast.net.

${ }^{4} \mathrm{RN}, \mathrm{PhD}$, Escola de Enfermagem de Ribeirão Preto, Universidade de São Paulo, WHO Collaborating Centre for Nursing Research Development, SP, Brazil. E-mail: ferocha@eerp.usp.br.
}

Corresponding Author:

Fernanda Ludmilla Rossi Rocha

Universidade de São Paulo. Escola de Enfermagem de Ribeirão Preto

Av. Bandeirantes, 3900

Monte Alegre

CEP: 14040-902 Ribeirão Preto,SP, Brasil

E-mail: ferocha@eerp.usp.br 


\section{Atribuições e funções dos enfermeiros do trabalho no Brasil e nos Estados Unidos}

Estudo transversal desenvolvido com o objetivo de delinear as responsabilidades e funções das enfermeiras do trabalho no Brasil e compará-las às atribuições das enfermeiras de saúde ocupacional nos Estados Unidos. A amostra foi composta por 154 enfermeiras do trabalho. Inicialmente, foi realizada a tradução para a língua portuguesa do instrumento de coleta de dados Job Analysis Survey of Occupational Health Nursing Practice, seguido da coleta e análise dos resultados, comparando-os aos dados obtidos num estudo realizado nos EUA. Foi constatado que a maioria das enfermeiras eram mulheres, brancas, com faixa etária entre 41 e 50 anos e trabalhavam em hospitais e centros médicos como enfermeiras clínicas ou administradoras. Além disso, observouse que as enfermeiras brasileiras despendem maior tempo em funções administrativas, atividades de consultoria e ações educativas, enquanto que as enfermeiras norteamericanas gastam um tempo significativamente maior desenvolvendo papéis educativos e de consultoria.

Descritores: Enfermagem; Saúde do Trabalhador; Enfermagem do Trabalho; Prática Profissional.

\section{Los papeles y funciones del enfermero de salud laboral en Brasil y en los Estados Unidos de America}

Investigación transversal realizada con el objetivo de definir los papeles y funciones de los enfermeros de salud laboral (ESLs) en Brasil y compararles con los de los Estados Unidos de América (EUA). La muestra fue compuesta por ciento cincuenta y cuatro enfermeros de salud laboral brasileños. Primero, fue realizada la traducción de lo instrumento Job Analysis Survey of Occupational Health Nursing Practice para el Portugués, seguido de la recolecta y análisis de los datos, comparándolos con los hallazgos de un estudio conducido en los EUA. Se encontró que la mayoría eran mujeres, blancas, entre 41 y 50 años e trabajan en hospitales y centros médicos como enfermeros clínicos y administradores. También se encontró que ESLs brasileños dedican más tiempo en funciones administrativas, seguidas de responsabilidades de consultoría y educador, mientras en los EUA los ESLs dedican significativamente más tiempo en funciones educativas y de asesoría.

Descriptores: Enfermería; Salud Laboral; Enfermería del Trabajo; Práctica Profesional.

\section{Introduction}

This study is part of a research project supported by the American Board for Occupational Heath Nurses, Inc - ABOHN, which aims to describe the roles of occupational health nurses and analyze their practice in different countries. One of the studies of this project was developed to create international guidelines in this specific nursing area in the United States, Korea and South Africa(1).

In Brazil, Occupational Health shows that the first focus on the triad health-work-disease started through Occupational Medicine as of 1830, with an expansion in the first half of the $20^{\text {th }}$ century. It was characterized by the model centered on the biological perspective of individual body medicine, under the occupational health physician, with a clinical-therapeutic approach to the analysis of the micro-environment and certain agents' pathogenic action. Due to the industrialization and urbanization process, the panorama of the capital-work relationship and new forms of occupational accidents and diseases, besides the biological aspects, the psychological and social demands in these relationships need to be taken into account as well(2).

Economic globalization, moving industries into the country, brought, in addition to the economic and social 
benefits, harm to many people's health environment. Automation, information and outsourcing determined transformations in the organization and work processes. They influenced workers and their health, and workers' health model had to be broadened and changed. Thus, Workers' Health is implemented as a multidisciplinary model, which considers workers' participation to understand how work affects the health-disease process; this model is created by the State, through the Brazilian public health system, Unique Health System (SUS), which directs actions to help workers throughout the country by means of the National Network for Comprehensive Worker's Health Care (Rede Nacional de Atenção Integral à Saúde do Trabalhador - RENAST) and the Reference Centers for Worker's Health (Centros de Referência em Saúde do Trabalhador - CEREST)(3).

Based on the worker's health model, the current Brazilian worker's health policy's challenge is to solve problems faced by the Brazilian work force, comprising 55 million people, $1 / 3$ of whom are women, $26 \%$ are involved in agriculture, $51 \%$ in the service sector, $23 \%$ in manufacturing and construction, seven million informal workers and two million unemployed(4).

According to the latest morbidity-mortality profile regarding the period from 2006 to 2007, the country recorded 1,165,322 occupational accidents with 5,602 deaths and 17,707 cases with permanent incapacities; injuries of fingers, hands and wrists represent $31.4 \%$ of occupational accidents(5). Work with obsolete and unsafe machines and equipment are related with the occurrence of severe occupational accidents causing incapacities(6). Thus, occupational health nurses play an important role in the search for better life and work conditions of these people.

The phase of economic instability around the world causes unemployment in Brazil to. The country presents unemployment rates above those of developed countries. In April 2009, the Brazilian Institute of Geography and Statistics (IBGE) officially stated that the rate was $8.9 \%{ }^{(7)}$. Thus, unemployment and informal employment (without legal records) are important issues that affect the health of the Brazilian working class.

With the purpose of historically contextualizing how occupational health nurses were developed in Brazil, it should be stressed that the development of modern nursing in Brazil began with the technical cooperation mission sponsored by the Rockefeller Foundation and directed by Ethel Parson in 1921.

Occupational health nursing in Brazil, previously named 'work nursing', started in the late 1950s. Although many nurses worked within the context of industrial medicine and occupational health since the 1940s, nursing in Brazil did not have regulatory involvement in protection of workers until 1959, when the International Labor Organization, by means of Resolution 112, stipulated the obligatory necessity of occupational health services within companies ${ }^{(8)}$.

According to the National Association for Occupational Nursing (ANENT)(9), Occupational Health Nurses (OHNs) refer to professionals who perform tasks related to occupational hygiene, medicine and safety, and integrate study groups to protect workers' health and safety. OHNs' responsibilities, also according to the association, include tasks that range from first aid to health promotion and prevention of occupational injuries and diseases.

About OHNs' education, the ANENT recommends a minimum course curriculum for the courses, with a necessary program content to develop the nursing professional, but does not provide certification, as done by the American Board for Occupational Health Nurses, Inc. $(\mathrm{ABOHN})$ in the USA. Federal and Regional Nursing Councils are responsible for determining and supervising the roles of nursing professionals, like of any other professionals involved in nursing practice in Brazil.

Since there are no studies about the responsabilities of occupational health nurses in Brazil, this study represents the first attempt to identify OHNs' roles in the country. Besides, considering that occupational health nursing plays an important role in the search for better life and work conditions of workers, this research provides valuable information on what tasks Brazilian OHNs perform to improve workers' health and safety and should be used as the basis for the development of practice guidelines for OHNs in Brazil.

This way, the purpose of this study was to describe the roles and functions of OHNs in Brazil and to compare them with those in the U.S.A. The specific aims were: to describe demographic and occupational characteristics of Brazilian OHNs; to identify major categories of roles and responsibilities for Brazilian OHNs; and to determine similarities and differences in roles and responsibilities in OHNs in Brazil and the USA.

\section{Method}

This is a descriptive cross-sectional research, using quantitative data analysis.

The instrument Job Analysis Survey of Occupational Health Nursing Practice was used to collect the data, developed by the American Board for Occupational 
Health Nurses, Inc. ${ }^{(10)}$. Permission to use the instrument was obtained from $A B O H N$. The License Agreement between $A B O H N$ and the Principal Investigator of the proposed study will be established when the proposed study receives funds from $\mathrm{ABOHN}$.

The first step of this study was the translation of the instrument Job Analysis Survey of Occupational Health Nursing Practice ${ }^{(10)}$ into Portuguese by two translators and an OHN faculty member who is fluent in both English and Portuguese. Prior to translation, the investigators and two translators reviewed the original English version and eliminated items not applicable to the Brazilian situation.

The researchers explained to each translator the purpose of the study and the importance of independent translation in order to assure reliability. The investigator compared the two translations with each other and with the original English version. Each translated question was reviewed to assure meaning, clarity and appropriateness to Portuguese. The questionnaire was back-translated from Portuguese to English, and then forwarded to a North American OHN for validation. After translation, the Portuguese version questionnaire was pilot-tested in a convenience sample of $10 \mathrm{OHNs}$, excluded from the final study sample. The purpose of this pilot study was to determine item clarity for the participants and testretest reliability of the Portuguese-version instrument. Test-retest reliability and correlation between two administrations of the same questionnaire were obtained within a 2-week period after the first administration. Upon completion of the second administration of the instrument, correlation of each item between test and re-test was calculated. Based on pilot study findings, the Portuguese-version instrument was changed.

The next step was data collection. The target population for this study comprised occupational health nurses who are members of ANENT. In 2006, of the total 983 ANENT members, 604 were OHNs and the others were occupational health nursing technicians and auxiliaries. OHNs were identified through a list provided by ANENT.

Data collection was performed using the mail survey method. A cover letter, informed consent, and the survey instrument were mailed to $604 \mathrm{OHNs}$, representing the study population. Data was collected from October to December 2006. Pre-stamped return envelopes were enclosed for the participants to use when they returned their completed questionnaires. Subjects were given three weeks to complete and return the questionnaires. To increase the participation rate, a reminder letter was sent to each of the non-respondents after three weeks.
Despite sending three reminders, 154 OHNs (25.5\%) replied to the mailed letters. Eighty invitation letters (11.9\%) were returned by postal service due to wrong addresses, and 20 OHNs (3.0\%) were excluded from the sample because they were retired.

After coding the variables and creating the data dictionary (codebook), a database was created using MS Excel SP, and validated through double entrance (typing). Uni-and bivariate statistical analysis were performed using Statistical Package for Social Sciences - SPSS software version 10.0 , and the following study variable measurements were obtained: qualitative variables: frequency distribution and association measurements in contingency tables; quantitative variables: central tendency measurements (mean, mode, median) and variability measurements (standard deviation and interquartile ranges). To compare tasks between groups with and without records, Mann-Whitney's non-parametric test was used, with significance set at 0.05 .

Next, the data of this study were compared with the findings of the job delineation study conducted in the USA ${ }^{(1)}$.

\section{Ethical Procedures for Human Subject Research}

The research was approved by the Institutional Review Board at the University of São Paulo at Ribeirão Preto College of Nursing.

\section{Results}

Prior to examining the roles and functions of Brazilian occupational health nurses, the instrument Job Analysis Survey of Occupational Health Nursing Practice was translated, developed by the American Board for Occupational Health Nurses, Inc. ${ }^{(10)}$, which supported this research in Brazil.

The translation process of the instrument was carried out without difficulty. The experts who evaluated the translation of the questionnaire into Portuguese suggested modification in the wording of a few questions, in order to adapt them to the reality of working of Brazilian OHNs. During the pilot-test, the number of questions was considered large by $10 \mathrm{OHNs}$, but we chose not to remove questions from the original instrument. Besides, the results of the pilot-test showed the adequacy of the data collection instrument for the proposed research objectives.

The results of this research are presented below by comparing them with the findings of the prior study conducted in the USA. 
According to the 154 OHNs, participants in the present study, $118 \mathrm{OHNs}(76.6 \%)$ are registered as OHNs with the Federal Nursing Council (COFEN). 34 OHNs $(22.1 \%)$, who have diplomas in this specialty, did not register with the COFEN and two OHNs (1.3\%) did not provide any information.

Brazilian OHNs presented the following demographic characteristics: $88.9 \%$ are women and $11.1 \%$ are men; $64.9 \%$ are between 41 and 50 years old, only $6.4 \%$ are under 30 and $2.6 \%$ are over 60 . Most (76.6\%) are white and the minority $(9.7 \%$ ) is mulatto (a person of mixed White and Black ancestry), 6.6\% are of Asian descent, $5.2 \%$ are Black, and $1.9 \%$ are of Indigenous descent. Approximately $69 \%$ work in the Southeast Brazil, $19.5 \%$ in the South, $7 \%$ in the Northeast, $2.6 \%$ in the CentralWest, and $1.9 \%$ in the North.

According to a study performed in the USA ${ }^{(1)}$ with 661 nurses certified for occupational health, $58 \%$ are COHN-S Type (Certified Occupational Health Nurse-Specialist) and $42 \%$ are COHN Type (Certified Occupational Health Nurse). Demographically, $94.8 \%$ are women, $45 \%$ are between 41 and 50 years old, 34\% between 51 and 60, and approximately $2.3 \%$ are older than 60 . Ethnically, $90.2 \%$ are Caucasian, of which $90.0 \%$ are white, and work proportionally distributed throughout the country, except for Mountain/Western regions.

About the work settings, $35.1 \%$ of OHNs work at institutions with over 5,000 employees, 20.8\% between 2,001 and 5,000 workers, and $14.2 \%$ less than 1,000 workers. Regarding the institutions where OHNs work, $16.9 \%$ of the respondents work at hospitals/medical centers. Those industries with at least 10 replies obtained were: faculties/universities (14.3\%), agriculture/forest/ sugar mill $(7.9 \%)$, chemical products and similar industries (7.2\%), manufacturing/textile industry $(7.2 \%)$, and local governments (6.5\%). Registered nurses have on the average 12.7 years of experience and those non-registered nine years of experience. OHNs' annual salary range between 8,000 and 49,000 US dollars, and the average monthly salary is 2,000 dollars.

The study performed in the USA ${ }^{(1)}$ reported that most nurses had on the average 11.1 years of experience for COHN nurses and 9.9 for COHN-S, and worked primarily at hospitals/medical centers (23.4\% COHN type and $23.4 \%$ CONH-S), followed by manufacturing industries, federal government, chemical industries, primary metals, communications, and food industries. Half the nurses worked in companies with 1,000 to 2,000 employees.
Regarding education, it was observed that 14 $(9.1 \%)$ Brazilian OHNs have additional specialty diplomas (in hospital management, health service management, urgency and emergency, health education, ergonomics, workers' health, and public health). Moreover, 19 OHNs $(12.3 \%)$ have a Master's degree: 15 (9.1\%) in nursing and four $(2.6 \%)$ in other areas (women's health, ergonomics, public health, and psychobiology); $18 \mathrm{OHNs}$ $(11.7 \%)$ have a Ph.D. degree: $17(11.1 \%)$ in Nursing and $1(0.6 \%)$ in Science.

\section{Roles and Responsibilities of Occupational Health Nurses}

Based on the descriptions of American Board for Occupational Heath Nurses (ABOHN), it was observed that clinical activities are the primary job responsibility for $30.5 \%$, followed by: manager or administrator $(12.3 \%)$, educator $(11.7 \%)$, nurse practitioner $(9.7 \%)$, occupational health service coordinator (8.4\%), and health promotion specialist (7.8\%). In the USA study ${ }^{(1)}$, OHNs' main primary job was clinician (30.7\%), followed by manager/administrator (23.0\%) and OHS coordinator (18\%). The Brazilian OHNs spend more time in manager roles $(33.05 \%)$, followed by consultant $(27.12 \%)$, educator $(26.01 \%)$, direct care $(24.27 \%)$ and others (33.16\%). Regarding the time spent on tasks, the USA study reported that $\mathrm{COHNs}$ spend $38.6 \%$ of their time on indirect care, while COHN-S spend $33.5 \%$. The latter spend significantly more time in education/advisory $\operatorname{roles}^{(1)}$

The Mann-Whitney test was applied to compare the scores of the 131 tasks. It was concluded that Brazilian OHNs reported the following as the most significant tasks (Mean Ranking): teaching workers individually, obtaining occupational health history, analyzing educational program objectives, providing work injury treatment, analyzing educational program objectives, using information regarding the organization's tax status to plan/implement programs and interventions, hiring occupational health personnel, establishing infection control guidelines and assuring compliance, preparing management reports, participating in the development of workers' benefit plans, participating in professional and community committees, and participating in interdisciplinary committees.

The USA study reported that the 10 most common tasks in both studied groups were: implementing confidentiality procedures, providing work injury treatment, obtaining occupational health history, developing a system of employee heath records, 
promoting occupational and environmental health nurse's role management, collaborating with other disciplines to promote and protect workers' health, assessing employees with work restrictions/make appropriate job placement recommendations, developing a network of qualified providers, evaluating workers' health status as related to their ability to perform a job, and documenting service delivery in worker health records. Approximately $80 \%$ of the tasks are similar among $\mathrm{COHN}-\mathrm{s}$ and COHN nurses. However, eight items showed significant differences, of which the two most significant items were "performing technical skills" and "evaluating home services"(1).

\section{Discussion}

Nursing in Brazil has advanced during the last several decades and is now a profession performed by various levels of practitioners. Currently, the active nursing workforce in Brazil consists of 118,707 nurses (university level professionals), 242,658 nurse technicians, and 506,565 nurse auxiliaries ${ }^{(11)}$.

Brazilian nurses obtain a degree from university courses (four to five years), and many continue their education through specialty and graduation courses, like the Master's and Ph.D. degree attested in this study. The demand for occupational health nurses in Brazil has grown over the last few years due to the increase in the number of industries, and the changes in some specific legislation norms, such as that stating that hospitals with over 501 workers, transportation companies with over 751 workers (Norm - 29), and rural companies with over 500 workers (Norm 31) are obliged to have an $\mathrm{OHN}^{(12)}$

These changes in legislation and economic development are directly associated with the job offers for Brazilian OHNs: hospitals, faculties, rural companies (especially now with the growth in sugarcane agriculture), manufacturing, chemical and similar industries and government agencies, in which the presence of OHNs is compulsory due to the higher occupational risk levels. The field for OHNs' practice has also expanded due to the current policy of occupational health care, which states that OHNs, as members of the regional and national Reference Centers for Workers' Health (CEREST), have to perform decentralized and structured curative, preventive, and rehabilitation actions through the National Network of Comprehensive Healthcare Services for Workers' Health (RENAST) and the Unique Health System(13).
As to the certification of occupational health nurses in Brazil, it does not follow the same standards as in the USA, where the nurse is subject to the examination by the American Board for Occupational Heath Nurses. Eligibility criteria for the Certified Occupational Health Nurse (COHN) and Certified Occupational Health NurseSpecialist (COHN-S) exams are Registered Nursing Licensure $(4,000$ work experience hours in occupational health in the past five years, 50 contact hours of continuing education in the past five years, and $\mathrm{COHN}-\mathrm{S}$ must have a bachelor's degree or higher).

Regarding roles and responsibilities, OHNs in developing and newly developed countries like Brazil share common professional goals of protecting workers from occupational injuries and diseases while promoting safety and health at the workplace ${ }^{(14)}$. Besides, the results showed that the Brazilian and North American OHNs perform managerial work as well as health promotion, education and research activities. However, it is generally known that $\mathrm{OHNs}^{\prime}$ roles and tasks differ between countries, considering their significant differences in work conditions, social and economic status, regulations and laws in occupational health and safety, and training and education programs for occupational health and safety professionals including $\mathrm{OHNs}^{(15)}$. There are also differences in the priority $\mathrm{OHNs}$ ascribe to the tasks performed, directly related with the patients' life and work situations, as well as with the organizational, socioeconomic, and cultural contexts of the institutions.

Comparing both studies, similarity was observed concerning the main primary job responsibility, which was the same for the USA and Brazil - clinicians and managers/administrators. However, there was a difference concerning the third main occupation, which Brazilian OHNs stated to be educator, while in the USA it was OHS coordinator. It is worth emphasizing that, in both studies, OHNs stated research responsibilities last in the OHN primary job responsibility list.

\section{Conclusions}

The primary responsibility of OHNs in Brazil is associated with the clinician's activities, followed by manager/administrator activity, educator, nurse practitioner, occupational health service coordinator and health promotion specialist. The OHNs spend more time in managerial roles, followed by consultant activities.

Similarities between Brazilian and American OHNs were identified. Demographically, most were 
women, white, between 41 and 50 years of age. Many OHNs work primarily at hospitals/medical centers and similarity was observed concerning the main primary job responsibility, which was the same for USA and Brazil - as clinicians and as managers/administrators. As for the differences in demographic characteristics, work is proportionally distributed in the EUA, while most jobs are in the Southeast of Brazil. In Brazil, most OHNs work in companies with over 3501 employees, while in the USA half the nurses work in companies with 1,000 to 2,000 employees. There was also a difference concerning the third main occupation, which Brazilian OHNs stated to be educator, while in the USA it was OHS coordinator. Brazilian OHNs spend more time in managerial roles, followed by consultant, educator, direct care and others; they spend $38.6 \%$ of their time on indirect care, while COHN-S spend $33.5 \%$. The latter spend significantly more time in education/advisory roles.

Due to the similarities and differences evidenced in the roles of American and Brazilian OHNs, it is recommended that information and knowledge exchange should be increased in order to improve scientific knowledge in OHN. This knowledge can also be employed in professional practice in different contexts. Despite the education of Brazilian OHNs, teaching still requires greater progress and specialty courses should meet the demands posed by the changes in the work world and the national and international recommendations of this professional category. The certification of Brazilian OHNs would benefit from professional practice and could be a strategy to fight for positions in the workplace. The present research results could support the development of occupational health nursing guidelines in Brazil, in agreement with the local reality and international practice in the referred area.

\section{Acknowledgments}

Grateful to the support of $\mathrm{ABOHN}$ for this research

\section{References}

1. Salazar MK, Kemerer S, Amann M, Fabrey LJ. Defining the roles and functions of occupational and environmental health nurses: results of a national job analysis. AAOHN J 2002; 50(1):16-25.

2. Murofuse NT, Marziale MHP. Doenças do sistema osteomuscular em trabalhadores de enfermagem. Rev Latino-am Enfermagem 2005; 13(3):364-73.

3. Duran EM, Robazzi MLCC, Marziale MHP. Conhecimento de enfermagem em saúde do trabalhador oriundo de dissertações e teses. Rev Gaúch Enferm 2007; 28(3):416-23.

4. Instituto Brasileiro de Geografia e Estatística - IBGE [homepage na internet]. Pesquisa nacional por amostragem de domicílio 2007. [acesso em: 10 dezembro 2008]. Disponível em: http://www.ibge.gov.br/home/estatistica/populacao/ trabalhoerendimento/pnad2007/default.shtm

5. Ministério da Previdência Social (BR) [homepage na internet]. Anuário estatístico da previdência social 2007. [acesso em 10 dezembro 2008]. Disponível em: http://www.previdencia social. gov. br/conteudoDinamico. php?id $=423$

6. Teixeira MP, Freitas, RMV. Acidentes do trabalho rural no interior paulista. São Paulo Perspec 2003; 17(2): 81-90.

7. Instituto Brasileiro de Geografia e Estatística - IBGE [homepage na internet]. Pesquisa mensal de emprego. Abril de 2009. [acesso em: 20 maio 2009]. Disponível em: http://www. ibge.gov.br/home/estatistica/indicadores/trabalhoerendimento/ pme_nova/defaulttab_hist.shtm

8. Marziale $\mathrm{MH}$, Hong O. Occupational health nursing in Brazil: exploring the world through international occupational health programs. AAOHN J 2005; 53(8):345-52.

9. Associação Nacional de Enfermagem do Trabalho - ANENT [homepage na internet]. Atribuições do Enfermeiro do Trabalho. [acesso em: 10 dezembro 2008]. Disponível em: http://www. anent.org.br/atribuicoes/index.htm

10. American Board of Occupational Health Nursing - ABOHN. Job analysis survey of occupational health nursing practice. Hinsdale, Illinois; 1999.

11. Conselho Federal de Enfermagem - COFEN [homepage on the internet]. Estatística detalhada dos profissionais de enfermagem no Brasil 2007. [acesso em: 10 dezembro 2008]. Disponível em: http://www.portalcofen.gov.br/2007/EstatisticaDetalhada.xls 12. Ministério do Trabalho e Emprego (BR). Manual de Legislação. Saúde e Segurança Ocupacional. São Paulo: Atlas; 2005.

13. Ministério da Saúde (BR) [homepage on the internet]. Portaria GM No 1679, de 19 de setembro de 2002. Dispõe sobre a estruturação da rede nacional de atenção integral à saúde do trabalhador no SUS e dá outras providências. [acesso em: 10 dezembro 2008]. Disponível em: http://portal.saude.gov.br/ portal/arquivos/pdf/ManualRenast07.pdf

14. Baggio MCF, Marziale MHP. A participação da enfermeira do trabalho no programa de conservação auditiva. Rev Latino-am Enfermagem 2001 set; 9(5):97-9.

15. Hong O. International perspectives: exploring the world through international occupational health programs. AAOHN J 2004; 51(5):191-2.

Received: Mar. $9^{\text {th }} 2009$

Accepted: Nov. $16^{\text {th }} 2009$ 